CCenter for Promoting Education and Research (CPER) USA,www.cpernet.org

\title{
The Socio-Political Role of Zombie Categories. A Case Study of the Referendum Amending Article 48 of The Romanian
} Constitution (6-7 October 2018)

\author{
Georgeta Ghebrea ${ }^{1}$ \\ Professor of Sociology \\ University of Bucharest \\ ORCID ID: https://orcid.org/0000-0002-6275-281X \\ E-mail: georgeta.ghebrea@fspub.unibuc.ro
}

\section{ABSTRACT}

Romania

Our scope was to explain the failure of the Referendum on the revision of Article 48 of the Romanian Constitution, regarding the definition of family (held in 2018 and known as the "traditional family referendum"). We hypothesized that in Romania the traditional family has become a "zombie" category, unable to produce an authentic mobilization of the social-political actors. Still, the traditional family represents an anchor that counteracts insecurity and anxiety caused by the "risk society" in which we live. This function is capitalized by social-political actors as a source of their legitimation. Our understanding was based on the processual analysis of this issue on the public agenda, from inflammation to extinction. This analysis clearly showed the process of gradual demobilization of the actors involved.

\section{Keywords: Zombie Category, Traditional Family, Political Field, Force Relations, Political Process}

\section{JEL Classification Code : I39, J13, R23}

\section{Introduction}

Our paper analyses the rise and fall of the "traditional family" referendum in Romania. This referendum was held in October 2018 and intended to change article 48 of the Romanian Constitution on the definition of family. The Constitution defines family in a gender-neutral manner, as a "union between spouses". On the contrary, the new Civil Code (Law 287/2009, Book II) defines the family in a restrictive way, as a "union between a man and a woman". The referendum proposed the transposition of the Civil Code definition into the Constitution, as well. Even though-provoking an intense public debate, this referendum eventually failed. It was invalidated, having a voting rate below the requested threshold of $30 \%$.

Our topic is important and relevant for the present European and global context. We can observe a transnational conservative movement for revaluation of the family in the public space, in legislation and policies, as well. Similar referenda were held in other East European countries, too (e.g., Croatia, Slovakia). The revaluation of the "traditional family" could be a strong tool for consolidating authoritarian politics. Our main research questions are: Why this referendum? And why its failure? The probable answer (and our hypothesis) is because the "traditional family" in Romania is a zombie (i.e., a living dead). Being a living dead, the "traditional family" was strong enough to motivate a referendum; being a living dead, the "traditional family" was incapable to win this referendum.

Our objective is two-fold: to demonstrate the decline of the "traditional family" in Romania but, at the same time, to demonstrate its powerful social-political role. Our original contribution is manifested on several levels. Theoretical: developing and applying the zombie category in the Romanian social and political context. Methodological: unifying temporal and spatial perspectives on the topic by combining processual and political field analyses. Comprehensive: understanding the political role of the zombie categories for social and political action. For these reasons, we think our study has an inferential value, as well.

Regarding the theoretical and conceptual frameworks, our research is deeply indebted to Ulrich Beck's conceptual innovation. In one of his famous interviews, he states that "zombie categories are 'living dead' categories which govern our thinking but are not able to capture the contemporary milieu" (Slater \& Ritzer, 2001). Even if dead, zombie categories are still socially useful because they help people coping with the rapid change in our contemporary world. Also, similarly to myths, they contribute to the social cohesion and mobilization of communities against perceived threats.

Due to their association with the rapid social change, zombie categories are linked to Beck's innovative concept, i.e., the risk society. This is an era in which the negative effects of progress determine the nature of the public debates that stimulate society (Beck, 2001). Therefore, new unexpected risks are arising and they are not covered by the existing - formal and informal social security arrangements. Consequently, people feel fears, anxiety, and incertitude. Our desacralized culture is insufficient to comfort them.

As political tools, the zombie categories are used especially by conservative and populist movements. One of the consequences of the recent spread of these movements in the European Union is promoting new legislation, which glorifies the 
nation and rejects human rights and European values. For instance, there were referendums in Croatia (2013), Slovenia (2015), and Slovakia (2015) for redefining - in Constitutions - family and marriage as unions between men and women. In these circumstances, certain authors believe that populism has become "a Constitutional project" (Blokker, 2019).

Populism is also connected to authoritarianism because it uses social conservatism as an instrument for consolidating a discretionary political power (Isaac, 2012). In Central and Eastern Europe, the zombie categories could be correlated with the nostalgia for communism. Communism promised a safe life, with stable jobs, access to housing, and a puritanical morality. Also, zombie categories could be a paradoxical effect of European integration, which created a fear of losing our national identity and sovereignty.

The "traditional family" is a zombie category because it doesn't exist anymore. The actual familial attitudes and behaviors are very different from those existing a couple of centuries ago. Important changes took place regarding progress towards equality between men and women, and between heterosexual and LGBTQ persons. Alternative family models are more and more accepted and the deinstitutionalization of marriage becomes visible, being "a weakening of the social norms that define partners' behavior." (Treas et al., 2014).

These changes are difficult to assimilate and, therefore, traditional morals are still active within certain social groups. Even the communist regimes that initially fought the family as a "bourgeois" institution ended by enforcing the traditional family morals. For instance, in Romania, Ceaușescu's regime banned abortion, contraception, and divorce (Ghebrea, 2000). Homosexuality was severely punished by the communist Penal Code. Also, the communist political regimes cultivated the fear of change and novelty, as a mean to defend their bureaucratic power and impose obedience.

Zombie categories are frequently used as part of symbolic politics and policies, i.e., they do not intend to improve or solve social problems but to ameliorate the image and legitimate the social-political actors (Marion \& Oliver, 2010). They "are concerned primarily with the message(s) political actors wish to convey and the specific audience(s) a proposal seeks to impress" (Ovink et al., 2016: 1).

\section{Materials and Methods}

Our goal is to understand the origin and failure of the 2018 referendum on redefining family in the Romanian Constitution. To accomplish this goal, our hypothesis refers to the role of the "traditional family" as a zombie category, i.e., a living dead but still playing an important social-political role. In Romania, the "traditional family" is no longer a lively and functional reality, but a fiction, unable to produce an authentic mobilization of the public and social-political actors, in general. Therefore, the referendum has failed.

To test this hypothesis, we used a mix of methods and techniques based on the secondary analysis. To demonstrate the transformation of the traditional family into a zombie, we proceeded to collect, analyze and synthesize statistical and demographic data, using the ideal type method (we considered the traditional family as an ideal type). To demonstrate the social and political role played by the traditional family, even if zombie, we used an analysis of the data provided by the opinion polls. We also used discourse analysis, media analysis, and document analysis.

To estimate the level and content of social and political mobilizations for the referendum under investigation, we went through the information and news on the events during the analyzed period (2006-2018), mirrored in public space, using the sites of some major news agencies and publications. We combined the spatial map with the temporal one.

The spatial map refers to the positioning of the different actors (parties, public authorities, public opinion, churches, associations, public intellectuals, media, international organizations, etc.) and the structuring, de-structuring, and restructuring of their relations, using political field analysis and force relations analysis. The political field is a dynamic space where political actors play the political game following rules and interests; their habitus and capital determine their different positions within the political field (Bourdieu, 1980). The force relations (rapports de force) are a foucaldian concept describing power as a game of ceaseless struggle and confrontations that transforms, strengthens, and reverses these relations Foucault, 1976). Finally, the force relations form coalitions - for or against different political measures - and build strategies for the state institutions and policy designs.

Our temporal map is based on processual analysis, from inflammation to extinction, of the referendum topic on the public agenda. The processual analysis is a method that takes into account the variable "time", placing the events in a more or less chronological framework. The process is a sequence of individual and collective events and actions carried out in a temporal context (Pettigrew, 1997). The main elements of our processual analysis are Context, Sequences, driving forces, Turning points, and Outcome (Bidart et al., 2013).

We considered the following relations between the research variables: The evolution of the family (the decline of the traditional family) in Romania is determined by a series of contextual factors, of which the most important are, in our view, the processes of modernization and urbanization, acculturation processes (diffusion of Western family attitudes and values), and globalization. These factors are characteristic of a risk society (rapid change, uncertainty, liquidity). This risk society produces social-political attitudes and moods that are characterized by anxiety, anomy, and alienation. To counteract this negative public 
CCenter for Promoting Education and Research (CPER) USA,www.cpernet.org

mood, the traditional family - even if almost extinct - continues to play an important role in politics and society, becoming a zombie category.

\section{Results and Discussion}

\subsection{The "traditional family" in Romania is dead}

First of all, we intend to demonstrate the quasi - disappearance of the "traditional family" in Romania. To do this, we need to conceptualize the different types of family. We use the "ideal type" methodology (Weber, 1949) for building family types: traditional and non-traditional. The non-traditional type could be divided into modern and postmodern.

Like all other typologies, this one is oversimplifying and has many limitations. To approach this typology, we created a mix of objective (behaviors) and subjective (attitudes and values) indicators.

Decreasing birth and fertility rates are characteristics of non-traditional families. In Romania, the birth rate is $8.6 \%$ and the total fertility rate is only 1.5 children per woman, which is insufficient for cohort replacement (Pisică, 2019: 9). Marriages are also decreasing: In Romania, in 2018, the marriage rate was only $6.5 \%$ (Pisică, 2019: 21). For comparison, the evolution of this indicator was: in 1950-11; in 1980-8; in 1990-7.7 (Ghebrea, 2000: 28). On the contrary, the divorce rate is increasing: 25\% of marriages in 2018 (Pisică, 2019: 24), compared to 20\% in 1989. Extra-marital births - 29.7\% of total annual births (Pisică, 2019: 10), celibacy - 20\% (Bădescu et al., 2007: 12) and single-parent families - 7\% of families with children (National Institute for Statistics, 2011; European Commission, 2019) are augmenting.

The age at the first marriage and the age at the first birth was traditionally very young in Romania, for both women and men, but the recent trends show a growing average age at the first marriage: 28.7 years for women and 31.9 for men in 2018 (Pisică, 2019: 23) and at the first birth: 27.9 years in 2018 (Pisică, 2019: 10). Family size is shrinking, below 3 members: 2.66 in 2011 (National Institute of Statistics, 2011). The traditional multi-generational families are only 17\% of the total families (Bădescu et al., 2007: 15) and single-child couples are more and more frequent. The first live-birth represents $50 \%$ of the total live birth in 2018 (Pisică, 2019: 10).

The women's status is different in the non-traditional families: they aren't anymore just housekeepers or carers, they are employed, many of them having professional careers. In Romania, the female activity rate is 56\% (Andrei, 2018: 120), still high, compared to traditional societies. Likewise, women in Romania have high educational status, being $52.7 \%$ of the population enrolled in higher education (Andrei, 2018: 317).

Regarding the non-traditional family values and attitudes, Romania became an individualistic society because the family plays rather a minor role in a person's life choices.

(Berevoiescu et al., 2000). A non-traditional family is characterized by weak family bonds, individual autonomy, and romantic love. In a survey carried out in Romania, 38\% of the respondents considered love as the most important thing for a couple (Bădescu et al, 2007:48). The non-traditional family abandons the patriarchal values and attitudes and it is founded on gender equality, the right to diversity, and freedom of choice. The most recent gender barometer in Romania (Grünberg, 2019) shows important progress in public opinion on gender equality, compared to the previous gender barometer, from 2000. The majority of the respondents agreed that women and men should share the responsibilities, both in private and public spheres (Grünberg, 2019: 70-77; 99).

Rigid and conservative attitudes are gradually replaced by progressive, flexible, liberal, and pluralist ones (ILGA-Europe, 2017). Thus, the social acceptance of behaviors like divorces, extramarital births, and abortion is widespread. Also, variable proportions of the Romanian public - 21-36\% - (European Commission, 2015) became favorable to equal rights for the LGBTQ persons and same-sex marriages.

In conclusion, the present state of the Romanian family shows that the traditional values, attitudes, and behaviors are no longer the majority and the traditional family became marginal in Romania.

\subsection{The "traditional family" in Romania is a living dead}

We have demonstrated that "the traditional family" is dead in Romania. Then, we will prove that this dead body is still alive, not only because the state continues to make policies in its favor (such as financial, housing, and adoption policies), giving preferential status to this type of family; but, also, because this quasi-fiction is still useful. First of all, the traditional family represents - for the ordinary people who form the public - a source of strength and support, an anchor to counterbalance the negative feelings caused by the unstable social environment and the rapid changes. The pre-existence of such feelings is demonstrated by the results of opinion polls conducted before the October 2018 referendum. Thus, the Romanian public mood is dominated by pessimism: 79\% of the interviewed people believe that "Romania goes in the wrong direction" (REALITATEA.NET, 2018). Also, anxiety is present, the main topics of concern being: rising prices, inflation, the cost of living and the general economic situation; health and social security; politics, corruption, and justice (Europa FM, 2019).

Alienation is another psychosocial aspect characterizing the public mood (European Commission, 2018): 68\% of the interviewed persons in Romania do not feel like European citizens and over 50\% have low trust in people and institutions. 
This negative public mood has been exploited by certain social and political actors, using the referendum as a tool for improving their public image and gaining legitimacy. But the public consultation has failed, and not just because the traditional family is almost non-existent within the Romanian society, but, also, because of the strong political mobilization against the referendum. We will demonstrate the strength of this mobilization by uniting time (through processual analysis) with space (through political field analysis).

\subsection{Understanding the failure of the 2018 referendum. Processual and political field analyzes}

The processual analysis is the "linkage between time and the changes observed in the phenomena under investigation" (Bidart et al., 2013: 743), having as main elements: context, sequences, driving/restraining forces, turning points, and outcome.

Context. One of the most relevant contextual characteristics was the discrepancy between the Constitution (2003) and the more restrictive Civil Code (passed in 2009, republished in 2011) regarding the definition of family. In our opinion, this discrepancy reflects the changes in public attitudes. After accession in the EU and during the economic crisis (2008-2012), intolerance, nationalism, and authoritarianism began to grow within the Romanian public opinion. We can explain that by a general demobilization after reaching the objective of becoming a member of the EU Moreover, these trends in public attitudes are present in most European societies, illustrating the rising populism. The non-governmental organizations are more and more active in Romania, compared to the '90. Another key contextual element is the Church's political and social role. In Romania, according to the last census (2011), atheism is quasi-nonexistent but trust in churches is decreasing during recent years (Gavrilaș, 2017). Therefore, churches feel like they lose ground and want to regain and consolidate their influence. Finally, the "traditional family" referendum took place in the middle of the electoral cycle, when the ruling parties started to erode and the opposition sought strategies to win the next elections. We can see from the presentation above that the context was unstable, turbulent, and polarized, and almost all actors strive to gain better public perceptions and trust.

Sequences: rise, peak, decline. The key moments in the rise of the issue on the agenda are: In 2006, the Alliance for Romanian Families has a first (non-materialized) initiative for replacing "spouses" with "man and woman" in art. 48 of the Constitution. In 2013, the Romanian Parliament begins a revision of the Constitution and, the same year, the newly founded Coalition for family (CfF) starts promoting the constitutional redefinition of family. The "traditional family" advocates try to prevent same-sex marriages and cohabitations. In 2015, the CfF launches the citizen initiative for changing art. 48 and the Draft Bill regarding this proposed change are published in the Official Journal. In 2016, the CfF (together with the most important churches) collects three million signatures for supporting its initiative. Consequently, the Constitutional Court approves the parliamentary debate on the revision of the Constitution.

The peak moments of the events under our investigation occur in 2016 and 2017. The Draft Bill is sent to the Senate and the parliamentary committees approve it. The ruling political party (Social-Democratic-SDP) becomes a supporter of the referendum for approving the CfF initiative. However, President Iohannis and certain opposition parties (such as the National Liberal Party-NLP and Union Save Romania -USR) notify the Constitutional Court about the new Referendum Law but the Court rejects the notification. CfF signs co-operation agreements with the main political parties (SDP, NLP, and ALDE). In 2017, the Chamber of Deputies and, in 2018, the Senate approve the Draft Bill for revision of the Constitution; USR is the only one party that each time voted against it. With all the necessary steps being taken, the referendum for popular approval could be organized now. The foreign organizations anti-gay, the Orthodox Church, and other confessions officially endorse the project. At the same time, the Romanian LGBT community collects 11000 signatures against the revision and other 30 NGOs join the protest.

The decline became visible in the second part of 2018 when the public protests and debates succeeded to structure boycotting as the best strategy against the referendum. The Constitutional Court declared the constitutionality of Law for the revision of the Constitution but the amicus curiae brief against it had a relevant impact on public debate. Another factor contributing to the decline was the governmental emergency ordinance for organizing the referendum for two days, instead of one. This decision created the perception that the referendum outcome is unsure and a desperate government made use of all the means it has. During the electoral campaign, the political parties became reluctant to overtly sustain the referendum, and the government was forced to affirm its neutrality. Only $\mathrm{CfF}$ and the churches remained active and, sometimes, they were sanctioned for propaganda breaking the campaign laws. At the same time, the online campaign promoting the boycott "Love is not voted!" was very successful among the young people. Finally, the referendum was held on 6 and 7 October 2018, but it was invalidated because of insufficient participation (according to the law, the minimum threshold for validation is $30 \%$ of the electorate).

Driving/restraining forces. We have used Bourdieu's theory on the political field (Bourdieu, 1980) to identify the dynamics of driving versus restraining forces that determined the outcome of the referendum. We extracted from his theory the main elements for a political field analysis: agents or actors (state actors, non-governmental actors, public opinion, international actors); their positions or locations referring to the considered issue (for, against, or neutral); their capital (social, cultural, economic, political resources); their habitus (political, social and economic ideologies); their interactions (hierarchies, subordination, cooperation, coalitions, conflicts); their actions; their objectives, priorities, and interests regarding the issue. 


\section{CCenter for Promoting Education and Research (CPER) USA,www.cpernet.org}

The result of the political field analysis is the political field mapping. In our case, the main actors, who played important roles in the process, were the following ones:

The Constitutional Court, in general, decided in favor of the referendum and the judges have given priority for debates and decision-making on this issue. We think the Constitutional Court was interested in improving its image and consolidating its legitimacy and, therefore, supported an issue that seemed popular.

The Parliament has decided in favor of the referendum because the majority and the ruling party (SDP) sustained the revision of the Constitution and the idea of the "traditional family". Romania's parliament is one of the public institutions having the least public trust and, therefore, it is very interesting to ameliorate its image.

President Klaus Iohannis was against the referendum, as we have seen in the sequence analysis. He represented the political opposition against the Government and the SDP. His constitutional powers are quite weak but his legitimacy is rather strong and he was interested in winning a second term. For this, he had to mobilize and maintain the trust of his electorate, which is more educated, urban, young, modern, and against the "traditional family".

The Government made the referendum its priority, wishing to acquire public support. The Government changed the law for organizing referendums, to increase electoral participation. The stake was not the balance between "yes" versus "no" answers to the revision of art. 48 of Constitution, but either to vote versus to boycott the referendum. Near the end of the electoral campaign, the Government realized the difficulty to achieve a voting rate of $30 \%$ and, therefore, its position became more neutral.

The National Council for Combating Discrimination (NCCD) reacted to discriminative actions and discourse against the LGBTQ community. Its president, Csaba Asztalos, sustained the equal rights for sexual minorities regarding marriage and family and disapproved of the revision of the constitutional definition of the family.

Besides the state actors, there were very relevant non-governmental actors, as well: political parties, churches, pressure groups, media, and public opinion.

Political parties were (including financially) involved in the electoral campaign, especially in local communities. SDP and NLP signed agreements with the CfF but, eventually, announced they were not involved. SDP, as a ruling party, exerted influence on the public institutions, to facilitate the referendum. It intended to gain votes in this way for future political elections. USR was very active in the boycotting and considered the referendum as an opportunity to consolidate its electorate and image as a progressive party.

The Orthodox, Catholic, and Neo-protestants churches supported very strongly the referendum and the "traditional family", to legitimize themselves, to improve their public image, and consolidate their inner coherence, confronting a more and more secular society.

The pressure groups were grouped in two major coalitions: $\mathrm{CfF}$ (pro-referendum and against the alternative families) and Coalition for the respect of rights and liberties-CRRL (against the referendum, pro-diversity, and human rights). The LGBTQ organizations (ACCEPT, MOSAIQ) also played an important role within the public debate.

Similar to civil society, traditional media as well were polarized. However, social media were the key communication factor and they had a major influence on attitude and behavior change (Bogdan, 2018).

The debate regarding the modification of the definition of the family in the Constitution and the organization of the referendum has not aroused the major interest of the public, as reflected in the opinion polls. Thus, in January 2018, 67\% of the interviewed persons considered that the revision of the Constitution is not necessary or it is not a political priority (Pușcaş, 2018). In September 2018, 51.26\% did not agree with convening such a referendum (DC News, 2018). Also in September 2018, another poll (Popescu, 2018) had the following results: 35\% said they will go to the referendum (of which 14\% would vote yes, $3 \%$ no, and the rest undecided) and 34\% would boycott the referendum. We can observe that chances for reaching the $30 \%$ voting rate were rather problematic.

International actors played also an important role in determining the referendum outcome. Similar to the national actors, they were divided into pro and con the "traditional" family. The European institutions (both the European Union-the Parliament, the Commission, and the Council as well as the Council of Europe, through the Venice Commission and the European Court for Human Rights - ECHR) signaled via public interventions the threat to human rights that this referendum can represent. Important international non-governmental organizations, such as Amnesty International, took a stand against the referendum. On the contrary, pro-family organizations (ADF International, In the Name of Family, La Manif pour Tous, Liberty Counsel, World Congress of Families, European Center for Law and Justice, European Dignity Watch) lobbied for the constitutional change of the family definition.

Turning points. If at the beginning of the process, the driving forces were more powerful, gradually they became weaker, the referendum lost the interest and approval of the electorate and restraining forces gained more influence. The driving forces were labeled - in the public space and among the electorate, as well - as anti-gay, which has become an uncomfortable label. Another uncomfortable label was the identification of the driving forces with the Government and the SDP. Therefore, the political field 
concerning the referendum was initially structured in two camps: anti-gay and pro-diversity, and then, it turned into pro and antiSDP camps. Finally, the strength ratio was reversed during the second part of the year 2018 because the anti-government and antiSDP feelings began to gain ground within the Romanian electorate. The main turning points, in our opinion, were: the government ordinance changing the referendum rules (two days instead of one, etc.); the news about the pro-referendum manipulative campaign (illegal posters, illegal campaigning in schools); respected and popular public persons (vloggers, digital influencers, artists, sportspersons) taking a stand against the referendum; the massive youth involvement in social media campaigning for boycotting the referendum; the political parties withdrew from the electoral campaign. These trends were reflected in public opinion, as shown above.

Outcome. The referendum for the "traditional family" took place on 6-7 October 2018 but it wasn't valid because of the high abstention rate (Central Electoral Bureau, 2018). The voting rate was only $20.41 \%$, under the threshold of $30 \%$ needed for validation according to the law. This failure proved the successful campaign for boycotting and illustrates the "No-Show Paradox": voters help their favored alternative by withholding their vote (Hayden, 2010). Only one county (Suceava, where the Orthodox Church is very wealthy and influential) was above the threshold.

\section{Conclusion}

Let's remember our research questions: why and how did the referendum for the "traditional family" (for the re-definition of the family in the Romanian Constitution) emerge in Romania and why did it fail?

Our hypotheses were confirmed: the traditional family in Romania is a zombie (living dead): it is dead because demographics demonstrate its extinction; it is living because our analysis of public mood proved the people's need for an anchor against the insecurity of the risk society; "traditional family" could be such an anchor. This need is used for acquiring trust, legitimacy, and a positive image, as proved by the discourse and actions of social-political actors during the pre-campaign and campaign for the 2018 referendum. Still, being "dead", the traditional family was unable to become truly relevant and mobilizing and, therefore, the referendum has failed.

Our processual and political field analyses have identified the turning points that have modified the strength ratio between driving forces and restraining forces during the pre-campaign and campaign. One of the most interesting findings is the transformation of the referendum, from an anti-gay/pro-diversity debate into a pro/anti-governmental and pro/anti-European debate. The driving forces became perceived and labeled as anti-gay, euro-skeptic, and pro-governmental and the restraining forces as pluralist, liberal, pro-European, and anti-governmental. This polarization is crucial for Romanian politics and society.

Zombie categories, including "traditional family", are linked to populism, to the glorification of the past, and the revival of a mythical golden age enforced by legislation changes, in many East-European countries. These phenomena exist in Romania, too, as demonstrated by our research. Therefore, we succeeded to prove the political role of the zombie categories in the political struggle.

Acknowledgments: This research did not receive any specific grant from funding agencies in the public, commercial, or not-forprofit sectors.

\section{References}

Andrei, T., ed. (2018). Romanian Statistical Yearbook 2017. Bucharest: National Institute of Statistics.

Bădescu, G., Kivu, M., Popescu, R., Rughiniş, C., Sandu, D. \& Voicu, O. (2007). Public Opinion Barometer. Couple Life. Buharest: Soros Foundation, Romania.

Beck, U. (2001). La Politique dans la Société du Risque. Revue du MAUSS, 1: 376-392.

Berevoiescu, I., Miroiu, M., Stănculescu, M. \& Weber, R. (2000). Gender Barometer. Bucharest: Open Society Foundation Romania.

Bidart, C., Longo, M. E. \& Mendez, A. (2013). Time and Process: An Operational Framework for Processual Analysis. European Sociological Review, 4: 743-751.

Blokker, P. (2019). Populism as a constitutional project. International Journal of Constitutional Law, 2: 536, accessed 22 August 2019, doi: 10.1093/icon/moz028.

Bogdan, S. (2018). Referendum pentru familie, ultima săptămână. Cum se poziționează partidele parlamentare. Îndemn la \#boicot pe rețelele de socializare". Gândul, 30 September 2018, https://www.gandul.ro/politica/referendum-pentrufamilie-ultima-saptamana-cum-se-pozitioneaza-partidele-parlamentare-indemn-la-boicot-pe-retelele-de-socializare17537075, accessed 19 April 2019.

Bourdieu, P. (1980). Questions de sociologie. Paris: Les Éditions de Minuit.

Central Electoral Bureau (2018). Rezultate Referendum 6-7 https://prezenta.bec.ro/referendum2018/, accessed 8 October 2018. 
CCenter for Promoting Education and Research (CPER) USA,www.cpernet.org

DCNews (2018). Referendum familie tradițională. Sondaj exploziv: peste 60.000 de voturi, 25 September 2018, https://www.dcnews.ro/referendum-familie-tradi-ionala-sondajul-momentului-peste-60-000-de-voturi_614976.html, accessed 19 April 2019.

Europa FM (2019). Știri interne, https://www.europafm.ro/sondaj-care-cred-romanii-ca-este-cea-mai-importanta-problema-cucare-se-va-confrunta-tara-noastra-in-2019/ accessed 20 April, 2019.

European Commission (2019), https://ec.europa.eu/eurostat/data/database accessed 13 May 2019.

European Commission (2015). Discrimination in the EU in 2015. Brussels: TNS Opinion \& Social, https://op.europa.eu/en/publication-detail/-/publication/d629b6d1-6d05-11e5-9317-01aa75ed71a1, accessed 23 January 2019.

European Commission (2018). Standard Eurobarometer. Autumn 2018. Public opinion in the EU, http://ec.europa.eu/commfrontoffice/publicopinion/, accessed 20 April, 2019.

Foucault, M. (1976). Histoire de la sexualité. Paris: Gallimard, (Vol. 1: La volonté de savoir).

Gavrilaş, C. (2017). Sondaj IMAS De ce a scăzut la 50\% încrederea în Biserică. Românii au început să perceapă că banul nu-i ochiul dracului, ci banul e ochiul Bisericii. Adevărul, 19 octombrie 2017, adev.ro/pbhsf9, accessed 16 March 2019.

Ghebrea, G. (2000). Regim social-politic şi viață privată. [Social Political Regime and Private Life]. Bucharest: University of Bucharest Press.

Grünberg, L., ed. (2019). Gender Barometer, Romania, 2018. Bucharest: Hecate.

Hayden, G. M. (2010). Abstention: The Unexpected Power of Withholding Your Vote. Connecticut Law Review, 2: 585-615.

ILGA-Europe (2017) Annual Review of the Human Rights Situation of Lesbian, Gay, Bisexual, Trans and Intersex People in Europe, https://www.ilga-europe.org/sites/default/files/Attachments/annual_review_2017_online.pdf, accessed 5 February 2019.

Isaac, J.C. (2012). From the Editor: Authoritarianism, Elections, Democracy? Perspectives on Politics, 4: 863-866.

Marion, N.E. and Oliver, W.M. (2010). Symbolic Politics, Criminal Justice Policy, and Third Political Party Platforms. Criminal Justice Policy Review, 21: 476-499.

National Institute of Statistics (2011). Population and Dwelling Census. http://www.recensamantromania.ro/rezultate-2/, accessed 21 May, 2019.

Ovink, S.M., Ebert, K. \& Okamoto, D. (2016). Symbolic Politics of the State: The Case of In-state Tuition Bills for Undocumented Students. Socius: Sociological Research for a Dynamic World, 2: 1, accessed 16 April 2019, doi: $10.1177 / 2378023116647969$.

Pettigrew, A. M. (1997). What is processual analysis?. Scandinavian Journal of Management, 4: 338.

Pisică, S., ed. (2019). Evenimente demografice 2018 [Demographic events 2018]. Bucharest: National Institute of Statistics.

Popescu, M. (2018. Câți români vor vota le referendum. Datele celui mai nou sondaj sunt clare!. Evenimentul Zilei, 28 September 2018, https://evz.ro/romani-vota-referendum-sondaj.html, accessed 19 April 2019.

Puşcaş, F. (2018). Sondaj CURS: Românii NU doreau schimbarea Guvernului. Câţi români vor alegeri anticipate. stiripesurse.ro, January 16, 2018, accessed 19 April 2019.

REALITATEA.NET (2018), https://www.realitatea.net/sondaj_2159525.html august 2018 accessed 20 April, 2019.

Slater, D., and Ritzer, G. (2001). Interview with Ulrich Beck. Journal of consumer culture, 1: 261-277.

Treas, J., Lui, J., \& Gubernskaya, Z. (2014). Attitudes on marriage and new relationships: Cross-national evidence on the deinstitutionalization of marriage. Demographic Research, 30: 1495, accessed 28 May 2019,

doi: 10.4054/DemRes.2014.30.54.

Weber, M. (1949). On The Methodology of Social Sciences (Shils, E.A., and Finch, H.A., eds.). Glencoe: The Free Press. 